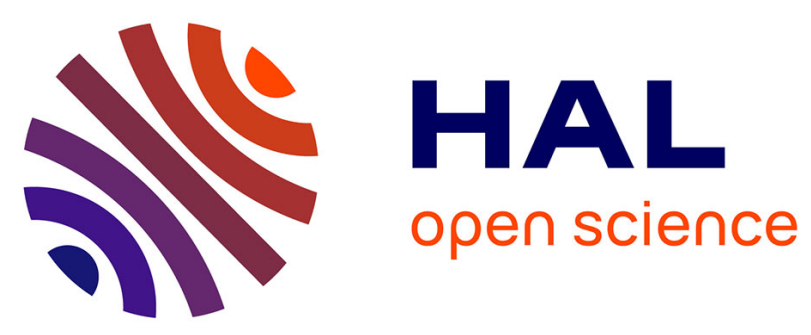

\title{
The impact and interplay of national and global CSR discourses: insights from France and Brazil
}

André Sobczak, Ligia Coelho Martins

\section{To cite this version:}

André Sobczak, Ligia Coelho Martins. The impact and interplay of national and global CSR discourses: insights from France and Brazil. Corporate Governance: An International Review, 2010, 10 (4), pp.445-455. 10.1108/14720701011069678 . hal-00771164

\section{HAL Id: hal-00771164 https://hal.science/hal-00771164}

Submitted on 11 Apr 2013

HAL is a multi-disciplinary open access archive for the deposit and dissemination of scientific research documents, whether they are published or not. The documents may come from teaching and research institutions in France or abroad, or from public or private research centers.
L'archive ouverte pluridisciplinaire HAL, est destinée au dépôt et à la diffusion de documents scientifiques de niveau recherche, publiés ou non, émanant des établissements d'enseignement et de recherche français ou étrangers, des laboratoires publics ou privés. 


\section{André Sobczak and Ligia Coelho Martins}

André Sobczak is Director, Institute for Global Responsibility, Audencia Nantes School of Management, France. Ligia Coelho Martins is Manager of the Responsibility and Sustainability Center, ISAE/FGV, Curitiba, Brazil

\section{The impact and interplay of national and global CSR discourses: insights from France and Brazil}

Throughout the world, the relations between business and society are undergoing profound changes, leading to a redefinition of the role and responsibilities of companies. On the one hand, our societies are facing ever more complex economic, social and environmental challenges, such as climate change, threats on biodiversity, increasing unemployment, poverty, urbanization or demographic change. These challenges can hardly be solved without the active contribution of the business sector, which has acquired new economic and political powers over the last decades and which often develops interesting technical and organizational innovations. On the other hand, the role of public authorities is increasingly weakened. National governments are grappling with tight budgetary constraints, while international regulations have difficulties to emerge or even regress in a context of global competition between national systems (Berthoin Antal et al., 2009).

Companies and their managers are therefore finding that it is no longer sufficient to define corporate social responsibility (CSR) in terms of reducing the negative impact of their activities on the economic, social and natural environment; stakeholders are expecting them to help address the challenges facing societies and to increase their positive impacts on their environments. This means developing new strategies and policies and in many cases it requires cooperating with other actors. Equally importantly, managers have to prove this positive impact by developing transparent reporting systems allowing their stakeholders to identify the companies' objectives, actions and results in these complex areas (Dubbink et al., 2008). Initially these expectations were limited to large companies producing consumer goods with well-known brands, but they have been expanding into all business sectors and all sizes of companies (Blomback and Wigren, 2009). Stakeholders are holding large companies responsible for their entire supply chain, thereby influencing the strategies and practices of small and medium-sized companies around the world (Sobczak, 2006; Baden et al., 2009). These trends, together with the emergence of various standards and management tools in the field, are favouring the mainstreaming of the integration of economic, social and environmental aspects in the business world (Gilbert and Rasche, 2008).

While these evolutions of the relations between business and society concern all parts of the world, the forms they take nevertheless vary from one context to the other, reflecting thus the cultural, socio-economic and legal traditions of each country (Berthoin Antal and Sobczak, 2007). CSR is usually defined as corresponding to the voluntary initiatives going beyond the law and other mandatory requirements (Carroll, 1999), the national legal context has an obvious impact on which corporate practices are considered as "explicit CSR" (Matten and Moon, 2008). Legal provisions may favour companies' commitment to CSR, either by imposing governance systems attributing a more or less important role to the companies' various stakeholders or by providing for mandatory social and environmental reporting to insure transparency of corporate strategies, policies and performance. Moreover, national legislation may create incentives for socially responsible behaviour, through fiscal policies or the inclusion of social and environmental criteria in the conditions for public tenders.

However, in the era of globalization, CSR discourses and practices evolve also as a result of developments beyond the nation State, such as initiatives of supranational organizations, practices of multinational companies (Griesse, 2007), NGOs, trade unions (Sobczak, 2007), the rapid evolution of technology and global connectivity, as well as the international academic discourse. The development of global CSR standards such as the UN Global Compact (Rasche, 2009), the Global Reporting Initiative (Levy et al., 2010) or the ISO 26000 Guidance on Social Responsibility (Schwartz and Tilling, 2009) contribute to a common understanding of the main priorities in the area of CSR and favour the sharing of experiences between companies and leaders from different countries. The transnational dimension of many companies and their stakeholders also favours a certain convergence of CSR practices and discourses. Companies having subsidiaries or suppliers in various countries tend to define common CSR discourses and practices, even if the local actors keep some freedom to adapt to their specific context. In a similar vein, NGOs and trade unions increasingly try to adopt global strategies when trying to influence the relations between business and society. Finally, management education 
and research in different countries increasingly develops common concepts in the field of CSR by closely cooperating in transnational networks, such as the EABIS (Wilson and Pickard, 2007) or the Principles of Responsible Management Education (Rasche and Escudero, 2009). For all these actors, the possibilities offered by the technologies of information and communications have increased the potential of sharing ideas and practices in the field of CSR, no matter how far they are away from each other.

As a consequence, CSR discourses and practices are a complex mix of national traditions and global influences. This situation creates a challenge for the different actors involved in the field of CSR. For managers in companies having activities in different parts of the world, it is difficult to establish a sound balance between the respect of common principles that have to apply worldwide and the necessary adaptation to the local specificities. The same challenge exists for the other stakeholder groups that have to develop coherent strategies with both universal claims that apply to all companies and local priorities that take into account the context of specific countries.

To highlight the interplay between these different influences and to contribute to its better understanding, this article compares and analyses CSR discourses and practices in two different national contexts: France and Brazil. Representing two of the largest economies in the world in two different continents, both countries have strong national cultures that have clearly shaped the way CSR is discussed and implemented through concrete initiatives. But the companies and other stakeholder groups in these countries are also exposed to global challenges that have had an impact on the evolution of both the CSR discourses and practices. Comparing the CSR discourse and practices in both countries thus helps to understand the impact of national traditions and international influences.

Based on a literature review as well as on interviews with representatives from companies and other stakeholder groups in both countries, the article is structured into two sections. The first section describes the different national cultural and legal contexts in France and Brazil, and in particular the role of public authorities, which continue to shape to a large extent the relations between business and society and thus the CSR discourse and practices in both countries. The second section analyzes the impact of international actors, be it NGOs or standardization organizations, on the relations between business and society, highlighting how they contribute to a certain harmonization of the CSR discourse and practises in France and Brazil, but also at a more global level. The article concludes with some general implications for managers and researchers that go beyond the comparison of the two countries.

\section{The impact of the national contexts on the CSR discourses and practices}

Compared with the USA, the discourses and practices in the area of CSR seem to be more recent in France and Brazil. France is often considered as an example of the countries in which CSR has for a long time been implicit (Matten and Moon, 2008), since the integration of economic, social and environmental responsibilities by companies was part of mandatory legislation. This explains that academic research has only recently started to pay an increased attention to the practices developed by French companies and other stakeholder groups in this area (Beaujolin and Capron, 2005; Berthoin Antal and Sobczak, 2007). As for Brazil, its companies had for a long time been less submitted to the pressure of stakeholder groups than those of other countries, in particular in the periods when the government was in the hands of the military. It was only quite recently that Brazilian companies have started at a broader level to develop more structured discourses and practices on CSR to reply to the expectations of international clients or, increasingly, to local consumers and NGOs that are more attentive to the economic, social and environmental challenges (Schmidheiny, 2006).

When the CSR discourses and practices finally became more explicit and structured in France and Brazil over the last decades, the primary focus in both countries was the social dimension rather than the environmental one, much more developed in the Nordic countries, even if the protection of the environment has since then also gained more attention from companies and other stakeholder groups in the two countries. In France, the CSR discourses and practices traditionally focused internally on labour-related issues rather than on external stakeholders (Berthoin Antal and Sobczak, 2007). Even if this situation has changed over the last years with the development of activities in the field of environmental protection or in favour of the community, this focus may explain the fact that French workers' representatives continue to be much more involved in companies' CSR policies than in other parts of the world. French companies have for example been pioneers and continue to be among the most active ones in the negotiation of transnational collective agreements on CSR with global union federations (Sobczak, 2007). In Brazil, the CSR discourses and practices traditionally focused on the role of business in community projects, in particular in the field of education, highlighting thus the government's difficulties in this area. 
The analysis of the cultural and legal context in France and in Brazil reveals a number of differences, which have shaped the relations between business and society in the two countries and thus the development of the CSR discourses and practices. A first difference concerns the link that is, or not, established with religious values. In France, the principle of secularity has constitutional value and explains that the Catholic Church is traditionally very discreet in economic affairs (Beaujolin and Capron, 2005). In France, the Church has thus not taken any particular initiative in the area of CSR. Some employers' associations that play an active role in the promotion of the CSR discourses and practices, such as the Centre of Young Leaders (Centre des Jeunes Dirigeants, CJD) are rather close to Christian values, but refuse to officially refer to them. In Brazil, by contrast, the Association of Christian Enterprise Directors (Associac,a o dos Dirigentes Crista os de Empresas) has had a rather strong influence on the CSR discourse, by defining as early as by 1965 a set of principles for responsible management (Simoes, 2008). More generally, the Catholic Church has to a certain extent influenced the CSR discourses and practices in Brazil through its tradition of assistance towards the poor that may explain the companies' philanthropic ideas.

A second difference is linked to the role of public authorities. Whereas France is an example of a country where the public authorities have deeply influenced the emergence and the development of CSR and its content through various legislation and other policies, the case of Brazil highlights on the contrary how the lack or the insufficiency of interventions by public authorities may lead to particularly important expectations among society towards business to fill in the gap. In other words, in both countries, public authorities have played an important role in shaping the CSR discourses and practices, but in two almost opposite ways. In France, the government has used its traditionally strong role in the economy to intervene directly by encouraging companies to define and implement more responsible strategies and by empowering other stakeholder groups. In Brazil, the government's influence in this area was much more indirect, insofar as it was mainly its incapacity to solve the country's social and environmental challenges that created a need for voluntary CSR initiatives.

\subsection{France: the active role of the public authorities in the development of CSR}

A major character of France is the strong role of the State whose intervention in economy is broadly accepted, if not expected. Since the French Revolution, the State is often seen as the only legitimate representative of the public interest. This may explain the early introduction in 1977 of a law on mandatory social reporting for companies with more than 300 employees (Rey, 1980). This reporting requirement covered more than 130 items relating to employment, wages, health and safety, training, working conditions and industrial relations. Admittedly, the scope of the report was relatively narrow, since it only covered employment-related matters, but it was a first step towards establishing a standardized set of detailed items in the field of CSR. Even more importantly, the reporting process specifically included a dialogue with employee representatives, the key stakeholders for the social report.

In 2001, the French legislator adopted a law expanding the scope of mandatory reporting for companies listed on the stock market (Law No 2001-240, Article 116). According to this law, the annual reports of any listed company shall contain certain information on how the management takes into account the social and environmental consequences of its activities. A governmental decree defines a set of quantitative and qualitative indicators related to social and environmental aspects, contributing thus to a certain harmonization of the information disclosed by French companies in the area of CSR, even if neither the law, nor the decree provide for sanctions in case of non-respect (Sobczak, 2003). With the adoption of this law, France became the first country to mandate triple bottom line reporting for publicly listed companies. Interviews with the French employers' association MEDEF show an evolution of the way they perceive this legislation. While the MEDEF had initially criticised this new administrative burden for companies, it has more recently recognized the law's positive impact on the quality of social and environmental reporting among French companies, which may allow them to have a better access to the growing market of socially responsible investments.

In France, the development of this market is also due to a large extent to the intervention of the State. The law on the generalisation of employee savings plans adopted in February 2001 (Law No 2201-152, Article 21) includes the requirement that employee saving funds specify the social, environmental or ethical considerations the fund management company must take into account when buying or selling stocks and securities. The fund's annual report must indicate how these considerations have been taken into account. This legislation allowed the major French trade unions to develop a CSR label for employee saving schemes, certifying their financial, social and environmental quality. This label aims at influencing the workers' representatives, who have to be involved in corporate decisions relating to the selection of saving schemes for 
their employees. In a similar vein, the law on the public pension reserve fund adopted in July 2001 requires disclosure of social and ethical criteria used for investment. The management board of this fund must report to the supervisory board on how the investment policy has taken into account social, environmental and ethical considerations. Currently, this public fund is one of the main socially responsible investors in France (Novethic, 2009).

In autumn 2007 the French State again illustrated its influence on the CSR discourse and practices, by organizing a broad stakeholder dialogue, known as the Grenelle de l'Environnement, to define the key priorities in the field of environmental protection and other aspects of CSR for the next five years (Stanziola Vieira and $\mathrm{Be}^{\prime}$ taille, 2008). The dialogue brought together representatives of business in society forming five stakeholder groups: the State, unions, employers, NGOs and local authorities. For three months, workgroups met to propose concrete actions in the area of CSR to be implemented at national, European and international level. In all, almost 330 people participated in these efforts, which took place during 40 plenary meetings, along with 13 workshops and a number of hearings. The proposal summaries represented a total of nearly 1,000 pages. These proposals were then opened up to debate by a range of public groups. Four consultation methods involving different segments of the public were set up: regional meetings (around 16,900 people attended); consultation via the internet (more than 300,000 visits to the site and over 72,000 visits to the eight thematic forums); parliamentary debate; submission to 31 bodies for consultation. Following this debate, the French president presented conclusions on the key priorities that are since then implemented through a series of laws, administrative decisions and other action plans. One of the decisions made in this process was to extend the principle of mandatory CSR reporting to non-listed companies with at least 500 employees. Furthermore, the conclusions contain the principle that managers must inform and consult workers' representatives on their CSR strategy and action plan, aiming thus at creating a regular stakeholder dialogue in all large French companies.

Finally, in France it has become increasingly common for public authorities at the national and the regional level to encourage the development of CSR by integrating social and environmental criteria in public procurement policies. Given the very high rate of public procurement in the French economy, which represents almost one fifth of the country's GDP, this strategy is a very powerful tool for public authorities to influence companies' policies, in line with the role the French society attributes to public authorities in the economic area.

\subsection{Brazil: the weakness of public authorities creating a need for voluntary CSR}

Brazil emerged from a period of military government in the 1980s that had created an environment in which companies and media were not allowed to express new ideas, nor to develop new ways of thinking, managing and defining their responsibilities (Simoes, 2008). The past decades have seen significant changes in the distribution of roles and responsibilities, including in the area of CSR. As compared to France, Brazil faces much greater social and environmental challenges. While France has a well developed and implemented labour and environmental law, leaving sometimes little space for voluntary CSR initiatives, in Brazil many companies, in particular the smaller ones, do not even meet the legal requirements (Capp et al., 2005). In many parts of the country the government seems not to be able to guarantee the respect of the existing labour and environmental laws, nor even to provide such essential public services as education to the whole population. Unlike France, the Brazilian government has not been very active in trying to promote CSR in the national economy. For example, the law adopted in 1975 that aims at providing the government with information on companies' policies related to employment and working conditions as well as at monitoring the respect of labour and social security law (Decreto-lei No. 76.900) is far from imposing the companies as much transparency as the French legislation on social reporting adopted at the same period. More significantly, it was not followed by other governmental initiatives in the area of CSR, even over the last decade when the question became increasingly present on the agendas of companies and other stakeholders.

In Brazil, it was thus almost exclusively private actors who shaped the CSR discourses and practices, while trying to compensate the lack of initiatives of public authorities. As in many other parts of the world, the development of the CSR discourses and practices in the 1990s was in particular favoured by the emergence of associations formed by companies that wanted to improve their practices in the field of CSR by sharing best practices. In Brazil, the Ethos Institute of Companies and Social Responsibility was created in 1998 by a group of influential business leaders with the aim to raise the awareness about CSR and to improve its management inside the companies. The Institute has started to develop research in this area. It has defined a set of CSR indicators for companies in Brazil and provides for information not only for the private sector, but also for researchers, the public and the non-profit sector. 
One of the main stakeholder groups that have favoured the development of CSR in Brazil is composed of the local NGOs. They have developed a recognized expertise in the definition and implementation of projects that help address the social challenges of the Brazilian society, in particular in the field of education. These NGOs have started to create various partnerships with companies that go beyond a purely financial relationship, for example by involving the companies' employees in the social projects. The NGO Todos pela Educac,a o brings together several companies and other stakeholders in order to achieve by 2022 five goals related to the improvement of education in the country. Among these goals, some consist of achieving the effective respect of federal laws or universal rights, showing thus the need for private actors to complement or even to replace the action of public authorities.

Local NGOs may also help foreign multinational companies to implement CSR discourses and practices that are adapted to the Brazilian context. For example, the Brazilian branch of the French multinational L'Ore' al developed an innovative CSR project in partnership with two NGOs in Rio de Janeiro and Sao Paulo (Sobczak and Coelho Martins, 2010). In 2009, the L'Ore' al headquarters requested their subsidiaries around the world to develop a social solidarity project to celebrate the group's 100th anniversary. The Brazilian branch decided to focus on an initiative that would allow young people from disadvantaged areas to access education, which is increasingly a condition to enter the job market. In order to create a link with the company's activity and to involve its network of stakeholders, the company decided to focus on the training for jobs in the beauty sector, such as hair or make-up. In order to implement the project, the company worked closely together with the local NGOs, which run the training programme, while L'Ore' al's employees, suppliers or clients offer some courses or coaching for the students.

The media, too, have significantly influenced the recent development of the CSR discourse and practices in Brazil (Vivarta and Canela, 2006). For example, the well-known sociologist Herbert de Souza launched a huge TV campaign at the end of the 1990s to promote the idea of social reporting, pushing more companies to use this tool (Griesse, 2007). The media also play an important role in disseminating NGO campaigns, as well as practices from other parts of the world, contributing thus to a certain change in the CSR discourses and practices in the country.

\section{The impact of international initiatives on the CSR discourses and practices}

While the different cultural and legal contexts continue to influence the CSR discourses and practices in France and Brazil, international actors contribute to a certain harmonization in the area. Multinational companies and their supply chains are a first category of actors that play an important role in this process, insofar as they favour the dissemination of CSR discourses and practices beyond national borders. In France, multinationals with headquarters in North America have played a leading role in the development of innovative practices aiming at promoting diversity and equal opportunities among the employees (Bellard and Ru" ling, 2001). In Brazil, foreign multinationals have often been among the pioneers in introducing the CSR discourses and practices in the country (Griesse, 2007). To a lesser extent, multinationals with their headquarters in France or Brazil may also have learnt from the CSR discourses and practices of their subsidiaries in other parts of the world (Berthoin Antal and Sobczak, 2007).

International NGOs are a second category of actors that have largely contributed to change the traditional CSR discourses and practices in France and Brazil, be it through campaigns aiming at raising the awareness on social and environmental problems among the population and criticizing corporate behaviour, or by developing innovative partnerships with companies in the field of CSR and sustainable development (Chartier and De' le'age, 1998). Finally, companies and other stakeholders in France and Brazil have been rather proactive in the integration of the emerging international standards and tools in the area of CSR. This has allowed them to evolve within a short period of time from a situation where their strategies and practices were mostly ignored at the global level to a situation where they actively contribute to the international debate, and even shape new standards, as we describe below.

\subsection{Development of partnerships between companies and NGOs}

As in other parts of the world, NGOs have played an important role in the recent development of the CSR discourse and practices in France and Brazil. In both countries, they contributed in particular to highlight the environmental dimension that had traditionally been less developed than the social one. NGOs have largely contributed to raise the awareness about problems and to highlight the role and responsibilities of companies in finding new solutions to reduce the negative impact of their activities and products. In this perspective, they publish reports, launch media campaigns and organize boycotts (Schepers, 2006). Greenpeace, for example has been very active in both countries and has launched several campaigns targeting the negative impact of specific 
companies on the natural environment. In France, this international NGO has launched campaigns highlighting the environmental impact of nuclear energy, targeting in particular the French electricity company EDF, or the companies in the food sector that were using genetically modified ingredients. The objectives of these campaigns was of course to change the legislation in these areas, but also to convince the companies to change their strategies and practise on a voluntary basis in order to avoid risks for their brand image. In Brazil, Greenpeace published a report in 2009 establishing a link between the negative social and environmental impact of red meat and leather production in illegal farms in the Amazon area and several well-known multinational companies, such as Adidas, BMW, Gucci and Wal-Mart. The report highlights in particular the fact that these farms often use forced labour and contribute to a large extent to the country's greenhouse gas emissions. Interviews with managers from these companies confirmthat the publication of the report has led the companies to review their policies and to cancel their contract with the illegal farmers cited in the report.

Other international NGOs have developed close partnerships with companies to help them with their expertise to improve their positive impact on the environment (Jonker and Nijhof, 2006). The French branch of the WWF, for example, has developed a clear strategy to develop corporate partnerships. Present in about 50 countries of the world, this international NGO has a very decentralized organization leaving a large autonomy to the national networks. The French branch has developed a partnership strategy towards companies, which is in line with the guidelines defined at the international level, but which is particularly proactive. Interviews with representatives from this NGO show that one of the reasons for this is the fact that the funds the NGO collects from individual donors are rather low in France as compared to other European countries, encouraging thus the managers to try to find other financial resources by concluding agreements with companies. More important, however, seems to be the positive impact the first experiences of co-operation have created in the past, leading the WWF in France to confirm and strengthen this strategy. Rather than to try to influence the public authorities or a sufficient number of citizens or consumers whose behaviour would then push the companies to become more responsible, the NGO has concluded that it may be more effective and much easier to co-operate with the market leader in order to improve its environmental performance, and thereby then create pressure on its competitors in the market.

With this aim, the WWF in France has created a special team in charge of corporate relations that manages both product and strategic partnerships (WWF, 2009). Product partnerships consist of adding the WWF's logo on products with a particularly low environmental impact. The rationale is that by being permitted to use this logo, which is one of the ten most known brands in the world, the company is likely to increase its sales. In return, the company pays a licence fee to the NGO. Strategic partnerships are more interesting insofar as they lead to the conclusion of a contract for a period of at least three years that defines precise quantitative objectives the company has to achieve in order to improve its environmental performance. Through its network of environmental specialists, the NGOs team supports the company's managers in defining and implementing concrete action plans to achieve these aims.

More recently, the Brazilian branch of WWF has developed a similar strategy of partnerships with companies, illustrating thus the impact of international actors on the homogenization of CSR discourses and practices in different parts of the world. Currently, there are fewer strategic partnerships with companies in Brazil than in France, but this number may increase quickly given the tradition of partnerships between companies and NGOs in this country, even if most of these partnerships have been concluded in the social area rather than in the environmental one (Damiano-Teixeira and Pompermayer, 2007).

\subsection{Recent involvement in international initiatives aiming at promoting CSR}

Over the last decade, French and Brazilian companies and other stakeholder groups have been actively involved in several international initiatives aiming at promoting CSR. This choice has brought the CSR discourse and practices in France and Brazil closer to what happens in other parts of the world, reducing to a certain extent the specific features of the relations between business and society in both countries. Significantly, this involvement has also allowed the French and Brazilian companies and other stakeholder groups to influence the spirit and the content of new international initiatives rather than simply being recipients of the standards developed by others.

A first example illustrating the involvement of French and Brazilian actors in international CSR initiatives is the UN Global Compact. In April 2010, out of the 8000 signatories of the ten principles relating to human rights, labour standards, environmental protection and the fights against corruption, more than 1,000 have their seat in France (659) or in Brazil (333). Together with Spain (931) and the USA (391), they are among the four countries with the highest number of signatories in the world. In France, this success is to a large extent linked to the involvement of the government that has encouraged the main French companies to sign the Global 
Compact in order support its activities at the international level aiming at promoting the protection of the environment. Some of these large companies have then asked their French suppliers to sign the ten principles as well. The mix of signatory organizations to the Global Compact is very different in France and Brazil. While at the international level more than 25 per cent of the signatories are not businesses, in Brazil this rate attains 30 per cent compared to only 10 per cent in France, illustrating the importance of the non-profit sector in Brazil. In France and Brazil, the signatories of the Global Compact have created very active national networks that organize workshops for the members, in particular to help them in drafting their communication on progress reports, but also to learn from each other on how to implement the ten principles in the local context. The national networks, especially those with a strong membership, such as the French and the Brazilian ones, are closely involved in the governance of the Global Compact and contribute to shape the future of this initiative, be it through decisions on how to promote the ten principles or on the evolution of the requirements in terms of reporting. They may also take more general initiatives aiming at promoting CSR and sustainable development. For example the Brazilian network has created an educational committee that tries to integrate these values in the national education plan.

Brazilian companies are also quite proactive towards the emerging international standards in the field of CSR. For example, 87 Brazilian sites have obtained the SA 8000 certification that focuses on the social responsibilities towards employees (Gilbert and Rasche, 2007). Brazil is consequently the fourth country in the world for the number of SA 8000 certifications. In comparison, only one French company has obtained the SA 8000 certification, which may be explained by the fact that the different labour standards covered by SA 8000 are mandatory according to French labour law. As for the ISO 14001 certification in the field of environmental management (Bansal and Hunter, 2003), it has been obtained by almost 2,500 Brazilian companies, corresponding to 57 per cent of all ISO 14001 certifications in South America (Gavronski et al., 2008). In France, about 3,500 companies have obtained this certification, which is more than in Brazil, but remains a rather low number compared to the other European countries.

More importantly, both France and Brazil have been highly involved in the elaboration of the future international CSR guideline ISO 26000, which will in principle be adopted by the end of 2010. Through the Brazilian Association of Technical Standards (ABNT), Brazil is one of the two leaders of the work group preparing this standard together with Swedish Standards Institute (SIS). In this role of coordination, the country can rely on its experience with the national CSR standard NBR 16001 that has been launched in 2004 to certify the existence of a management system in the fields of ethics, citizenship and sustainable development (NRB 16001, 2004). France has also been actively involved in the drafting of the future ISO 26000 guidelines through its national standardization body AFNOR. The latter has organized a broad consultation process among the different French stakeholders based on local working groups in order to integrate their expectations into the international debate about the new standard. While waiting for the adoption of the future ISO 26000 guidelines, AFNOR has tested over the last years, different national CSR guidelines and standards, such as SD 21000 and AFAQ 1000NR.

\section{Conclusions}

This article shows the impact of both national traditions and recent international influences on the CSR discourses and practices in France and in Brazil. While it highlights the tendency to a certain harmonization in the area through the various activities of multinational companies, international NGOs and standardization organizations, it also shows that cultural and legal traditions continue to play an important role in the definition of the relations between business and society. Managers in multinational companies thus have to pay attention when defining their CSR strategies to create a balance between the respect of certain universal values, in particular those integrated in the emerging international standards, and the need to adapt to the different national contexts of their subsidiaries or suppliers. In some countries, such as France, the respect of the national specificities is mandatory by law; in others, such as Brazil, local stakeholders expect it, in particular from multinational companies, which are perceived as having specific responsibilities reflecting their economic powers. In both cases, the best way to find the right balance consist of engaging with the local stakeholder groups that may help the managers to understand the context and to implement effective projects improving the company's positive impact on its natural, economic and social environment. However, more research has to be conducted on the conditions allowing the long-term success of such local partnerships between very different actors, as well as on the ways allowing the managers to learn from these local partnerships to improve their global CSR discourses and strategies. 


\section{References}

Baden, D.A., Harwood, I.A. and Woodward, D.G. (2009), "The effect of buyer pressure on suppliers in SMEs to demonstrate CSR practice: an added incentive or counter productive?", European Management Journal, Vol. 27 No. 6, pp. 429-41.

Bansal, P. and Hunter, T. (2003), "Strategic explanations for the early adoption of ISO 14001", Journal of Business Ethics, Vol. 46 No. 3, pp. 289-99.

Beaujolin, F. and Capron, M. (2005), "France. Balancing between constructive harassment and virtuous intentions", in Habisch, A., Jonker, J., Wegner, M. and Schmidpeter, R. (Eds), Corporate Social Responsibility across Europe, Springer, Berlin/Heidelberg/New York, pp. 97-108.

Bellard, E. and Ru" ling, C.C. (2001), "Importing diversity management: corporate discourses in France and Germany", working paper, Ecole des Hautes Etudes Commerciales, Université de Genève, Geneva.

Berthoin Antal, A. and Sobczak, A. (2007), "Corporate social responsibility in France: a mix of national traditions and international influences", Business \& Society, Vol. 46 No. 1, pp. 9-32.

Berthoin Antal, A., Oppen, M. and Sobczak, A. (2009), “(Re)discovering the social responsibility of business in Germany", Journal of Business Ethics, Vol. 89, pp. 285-301.

Blomback, A. and Wigren, C. (2009), "Challenging the importance of size as determinant for CSR activities", Management of Environmental Quality: An International Journal, Vol. 20 No. 3, pp. 255-70.

Capp, J., Elstrodt, H.-P. and Jones, W.B. (2005), "Reining in Brazil's informal economy", The McKinsey Quarterly, No. 1, pp. 9-11.

Carroll, A.B. (1999), "Corporate social responsibility. Evolution of a definitional construct", Business \& Society, Vol. 38 No. 3, pp. 268-95.

Chartier, D. and De' le'age, J.-P. (1998), "The international environmental NGOs: from the revolutionary alternative to the pragmatism of reform", Environmental Politics, Vol. 7 No. 3, pp. 26-41.

Damiano-Teixeira, K.M. and Pompermayer, M.M. (2007), “Corporate social responsibility: profile and diagnosis of 797 programmes developed in Brazil”, Business \& Society Review, Vol. 112 No. 3, pp. 343-67.

Dubbink, W., Graefland, J. and Van Liedekerke, L. (2008), “CSR, transparency and the role of intermediate organizations", Journal of Business Ethics, Vol. 82 No. 2, pp. 391-406.

Gavronski, I., Ferrer, G. and Paiva, E.L. (2008), "ISO certification in Brazil: motivations and benefits", Journal of Cleaner Production, Vol. 16 No. 1, pp. 87-94.

Gilbert, D.U. and Rasche, A. (2007), "Discourse ethics and social accountability: the ethics of SA 8000", Business Ethics Quarterly, Vol. 17 No. 2, pp. 187-216.

Gilbert, D. and Rasche, A. (2008), "Opportunities and problems of standardized ethics initiatives: a stakeholder theory perspective", Journal of Business Ethics, Vol. 82 No. 3, pp. 755-73.

Griesse, M. (2007), “Caterpillar's interactions with Piracicaba, Brazil: a community-based analysis of CSR", Journal of Business Ethics, Vol. 73 No. 1, pp. 39-51.

Jonker, J. and Nijhof, A. (2006), "Looking through the eyes of others: assessing mutual expectations and experiences in order to shape dialogue and collaboration between business and NGOs with respect to CSR", Corporate Governance: An International Review, Vol. 14 No. 5, pp. 456-66.

Levy, D.L., Brown, H.S. and Jong, M. (2010), "The contested politics of corporate governance: the case of the global reporting initiative”, Business \& Society, Vol. 49 No. 1, pp. 88-115. 
Matten, D. and Moon, J. (2008), '“Implicit' and 'explicit' CSR: a conceptual framework for a comparative understanding of corporate social responsibility”, Academy of Management Review, Vol. 33 No. 2, pp. 404-24.

Novethic (2009), Chiffres 2008 et analyse du marché français de I'ISR, Novethic, Paris, available at: www.novethic.fr/novethic/upload/etudes/Synthese marche ISR 2008.pdf

Rasche, A. (2009), "'A necessary supplement': what the United Nations global compact is and is not", Business \& Society, Vol. 48 No. 4, pp. 511-37.

Rasche, A. and Escudero, M. (2009), "Leading change. The role of the principles for responsible management education", Zeitschrift fu“ r Wirtschafts- und Unternehmensethik, Vol. 10 No. 2, pp. 244-50.

Rey, F. (1980), “Corporate social performance and reporting in France”, in Preston, L.E. (Ed.), Research in Corporate Social Performance and Policy, Vol. 2, JAI Press, Greenwich, CT, pp. 291-325.

Schepers, D.H. (2006), "The impact of NGO network conflict on the corporate social responsibility strategies of multinational corporations", Business \& Society, Vol. 45 No. 3, pp. 282-99.

Schmidheiny, S. (2006), "A view of corporate citizenship in Latin America", Journal of Corporate Citizenship, Spring, pp. 21-4.

Schwartz, B. and Tilling, K. (2009), "'ISO-lating' corporate social responsibility in the organizational context: a dissenting interpretation of ISO 26000", Corporate Social Responsibility \& Environmental Management, Vol. 16 No. 5, pp. 289-99.

Simoes, C.P. (2008), Responsabilidade social e cidadania: conceitos e ferramentas, Servic, o Social da Indu' stria (SESI), Brasilia.

Sobczak, A. (2003), "L'obligation de publier des informations sociales et environnementales dans le rapport annuel de gestion: une lecture critique de la loi NRE et de son de'cret d'application", Semaine Juridique Entreprise, No. 14, pp. 598-604.

Sobczak, A. (2006), "Are codes of conduct in global supply chains really voluntary? From soft law regulation of labour relations to consumer law", Business Ethics Quarterly, Vol. 16 No. 2, pp. 167-84.

Sobczak, A. (2007), "Legal dimensions of international framework agreements in the field of corporate social responsibility”, Relations Industrielles - Industrial Relations, Vol. 62 No. 3, pp. 466-91.

Sobczak, A. and Coelho Martins, L. (2010), "Educating young people from disadvantaged areas to help them to access jobs in the beauty sector. Some lessons from a partnership between L'Oréal and two Brazilian NGOs", working paper, Institute for Global Responsibility, Nantes.

Stanziola Vieira, R. and Be' taille, J. (2008), "Grenelle de l'Environnement: is France making up for lost time?", in Bosselmann, K., Engel, R. and Taylor, P. (Eds), Governance for Sustainability. Issues, Challenges, Successes, IUCN, Gland, pp. 201-4

Vivarta, V. and Canela, G. (2006), "Corporate social responsibility in Brazil. The role of the press as watchdog", Journal of Corporate Citizenship, pp. 95-106.

Wilson, A. and Pickard, S. (2007), "European Academy of Business in Society. Knowledge development, research and learning upgrade", Journal of Corporate Citizenship, No. 25, pp. 109-10.

WWF (2009), Rapport Partenariats Entreprises, WWF, Paris.

Further reading

Berthoin Antal, A., Dierkes, M., MacMillan, K. and Marz, L. (2002), "Corporate social reporting revisited", Journal of General Management, Vol. 28 No. 2, pp. 22-42. 